\title{
What Is The Impact of Atopic Diseases On Symptoms Dimension of Attention- Deficit/Hyperactivity Disorder: A Systematic Review And Meta-Analysis
}

Yu-Chieh Chuang

Taipei Medical University

Ching-Yun Wang

Taipei Medical University Hospital

Wei-Lieh Huang

National Taiwan University Hospital Yunlin Branch

Liang-Jen Wang

Kaohsiung Chang Gung Memorial Hospital, Chang Gung University College of Medicine

Ho-Chang Kuo

Kaohsiung Chang Gung Memorial Hospital, Chang Gung University College of Medicine

Yang-Ching Chen

Taipei Medical University Hospital

Yu-Jui Huang ( $\nabla$ yujui0515@gmail.com )

Taipei Medical University Hospital

Research Article

Keywords: neuroscience, psychology, hypothesized, longitudinal

Posted Date: September 8th, 2021

DOI: https://doi.org/10.21203/rs.3.rs-753342/v1

License: (c) (i) This work is licensed under a Creative Commons Attribution 4.0 International License. Read Full License 


\section{Abstract}

Studies in the field of neuroscience and psychology have hypothesized that a causal association exists between atopic diseases and attentiondeficit/hyperactivity disorder (ADHD). Previous systematic reviews and meta-analyses have reported a higher risk of ADHD in children with atopic diseases; however, the relationship between ADHD symptoms and atopic diseases remains unclear. We systematically reviewed observational cross-sectional and longitudinal studies to investigate the relationship between atopic diseases and ADHD symptom severity (hyperactivity/impulsivity and inattention). The majority of studies showed a statistically significant association between atopic diseases and both ADHD symptoms, with substantial heterogeneity in the outcome of hyperactivity/impulsivity. Inconsistent results were observed in the subgroup analysis of different exclusion criteria for patients with ADHD. Our study indicated that atopic diseases not only increase the risk of ADHD but also are associated with ADHD symptom severity. This association was even observed in children with subthreshold ADHD, indicating that atopic diseases play a role in the spectrum of ADHD symptom severity.

Trial registration: This study was registered on PROSPERO (registration ID: CRD42020213219).

\section{Introduction}

In the past decade, atopic diseases have been a cause of increased concern because of their substantially high prevalence(approximately $20-40 \%$ ) worldwideThe International Study of Asthma and Allergies in Childhood Steering Committee, ${ }^{1}$, with more prominent increasing trend in developing countries ${ }^{2}$. Atopic march, defined as the development of atopic dermatitis in infancy and subsequent allergic rhinitis and asthma in later childhood, can cause fatigue; attention, learning, and memory deficits; and depression. Moreover, atopic diseases have been reported to considerably affect children's sleep, school performance, development, and quality of life ${ }^{3 ;}{ }^{4}$. In addition, recent studies have reported that the parents or main caregivers of children with atopic diseases, particularly those with multiple atopic diseases, experience considerable stress and psychosocial burden ${ }^{4-8}$ Thus, increasing public attention has been focused on the management of atopic diseases ${ }^{8}$.

Attention-deficit/hyperactivity disorder (ADHD) is among the most common neuropsychiatric disorders in children and adolescents, with a prevalence of approximately $5 \%$. ADHD is characterized by hyperactivity, impulsivity, and inattention that lead to not only functional impairment but also executive function impairment and emotional dysregulation ${ }^{9,10}$. ADHD can be caused by multiple factors (e.g., genetic, epigenetic, and environmental). Moreover, studies have indicated that ADHD occurs due to immature brain development, and it may also be accompanied by other neurobehavioral developmental delays and even intellectual disability ${ }^{10,11}$. Many studies have reported that ADHD symptoms were still observed in adulthood in a majority of patients with ADHD, even in those with adult $A D H D$ who did not meet the criteria for ADHD in their childhood ${ }^{12-14}$. Adult patients with ADHD experience a financial burden and may even require considerable support ${ }^{14}$. These findings indicate that ADHD is a matter of considerable concern in child and adolescent psychiatry.

A previous study investigated the relationship between atopic diseases and ADHD ${ }^{15}$. A higher risk of ADHD was noted in patients with all three atopic diseases, namely atopic dermatitis, asthma, and atopic rhinitis (i.e., atopic march) ${ }^{16,17}$. In addition, children with both atopic diseases and ADHD had an increased risk of developing more severe ADHD symptoms compared with those with only ADHD ${ }^{18}$. Although several meta-analyses and systematic reviews have strongly supported the relationship between atopic diseases and ADHD ${ }^{17,19-21}$, they still had many limitations. The heterogeneity observed in some systematic reviews might have affected their findings; for instance, some reviews did not include studies with standard inclusion and exclusion criteria, and whether the atopic and control groups included patients diagnosed as having ADHD remained unclear ${ }^{16,19}$. In addition, few studies have reported a relationship between atopic diseases and subthreshold ADHD. Moreover, no systematic review and meta-analysis has examined whether atopic diseases affect the severity of both hyperactivity/impulsivity and inattention-the two main symptoms and diagnostic criteria related to ADHD.

In this systematic review and meta-analysis, we reviewed studies examining the relationship between atopic diseases and the severity of ADHD symptoms including hyperactivity/impulsivity and inattention. In addition, we explored more precise value of this relationship by defining inclusion and exclusion criteria for groups. By doing so, we could exclude some confounding effects and provide additional information regarding the relationship between atopic diseases and subthreshold ADHD; this involved examining the data of children without a previous diagnosis of ADHD but who had a risk of developing more severe ADHD symptoms.

\section{Results}

\section{Search results}

Through our literature search, we identified 2406 studies (753, 1620, and 33 from PubMed, Embase, and Cochrane Library, respectively). Five additional studies were identified through other sources. Using EndNote, we found that 405 studies were duplicates and we thus excluded them. Subsequently, we screened the titles and eligibility of the remaining 2006 studies. During title screening, we removed 727 studies because they were not relevant to our research. During abstract screening, from the remaining 1279 studies, we removed 673 because of their nonrelevance. Additionally, we excluded 70 studies because they were not original research. Moreover, 393 and seventeen studies were excluded because they did not include a relevant control group and were letters or replies, respectively. Subsequently, after reviewing the full texts of the remaining 126 studies, we excluded 100 studies, 23 of which had double or serial publications, 46 had missing data, and 32 were not case-control, cross-sectional, or cohort studies. Finally, we included the remaining 25 studies in this systematic review for qualitative synthesis, and 12 of them were included in the quantitative review and meta-analysis. The procedure for study inclusion is shown in Appendix A in the Supplementary Materials.

\section{Qualitative systematic review}


In 25 studies including 58,253,734 participants, the researchers examined the relationship between atopic diseases and ADHD symptom severity by displaying prevalence of $A D H D$ in patients with atopy, odds ratios(OR) of ADD/ADHD in children with atopy, or calculating scores for hyperactivity/impulsivity, inattention, or total ADHD symptoms. Table 1 lists the characteristics of included studies. Most of the studies assessed atopic diseases by using parental questionnaires or based on their diagnosis by physicians or dermatologists according to specific diagnostic criteria, including the Global Initiative for Asthma guidelines, Allergic Rhinitis and its Impact on Asthma guidelines, and UK Working Party criteria. Seven study groups ${ }^{22} ;{ }^{23,24}$ conducted an advanced additional test for atopy such as the skin-prick test and blood sampling for serum-specific IgE (MAST or Phadiatop tests). The included studies used different outcome scales including the Conners' Parent Rating Scale; ADHD Rating Scale; Swanson, Nolan, and Pelham IV Scale; Child Behavior Checklist, Early Childhood Inventory-4, the German ADHD Rating scale (FBB-HKS), and the Strengths and Difficulties Questionnaire (SDQ). Despite the variability in outcome scales, most scales were designed on the basis of the DSM-IV criteria. Four studies ${ }^{25-28}$ adopted the SDQ, which is not derived from the DSM-IV criteria; however, the SDQ has been reported to be relevant to the DSM-IV 29,30 , He et al. $2013,{ }^{31}$. Most of the studies investigated the effect of confounding factors, including age, sex, multiple atopic diseases, the comorbidity with ADHD, severity of atopic diseases, persistent atopic diseases, and stressful parenting. Twelve of the thirteen studies examining the outcome of total ADHD symptoms reported a significant relationship between the severity of ADHD symptoms and atopic diseases. Furthermore, 8 of the 14 studies examining the outcome of hyperactivity and 11 of the 13 studies examining the outcome of inattention demonstrated a significant relationship between the severity of the examined ADHD symptoms and atopic diseases.

Two of the three studies reported a significant association between the comorbidity of ADHD and atopic diseases in patients with ADHD. Ten studies reported a significantly positive correlation among atopic diseases, sleep disturbance, and ADHD or an increased risk of ADHD in children with atopic diseases. One research group ${ }^{32}$ performed structural equation modeling to determine interactions among eczema, asthma, rhinitis, sleep, and behavior disorders. In three studies, the computerized comprehensive attention test (CAT) was performed, a more objective and precise measurement tool, to assess attention deficit, and they obtained results similar to those of other studies, thus supporting our hypothesis that atopy increased ADHD symptoms severity. In addition, seven studies examined treatment modalities for atopic diseases; however, additional randomized controlled trials are required to obtain more consistent results and causal relationships. The included studies evaluated several confounding factors such as age, sex, and atopic disease severity. Additional detailed information is provided in Table S1 in the Supplementary Materials.

\section{Quantitative review and meta-analysis of longitudinal studies}

Twelve studies including 20,928 participants examined the relationship between at least one type of atopic disease and the severity of ADHD symptoms, either hyperactivity/impulsivity or inattention, by including control groups consisting of participants without atopic diseases. Table 2 lists the characteristics of included studies. Of the included studies, two were case-control studies and the remaining were cross-sectional studies.

\section{Overview of total ADHD symptoms through a meta-analysis}

In terms of the outcome of total ADHD symptoms, the overall effect exhibited a statistically significant association with a $95 \% \mathrm{Cl}$ of $0.26-0.53$ (Fig. $1 \mathrm{a})$. We observed considerable heterogeneity among subgroups with an $\mathrm{I}^{2}$ value of $92.8 \%$. The funnel plot displayed no asymmetry ( $p>0.05 ;$ Fig. $\left.1 \mathrm{~b}\right)$.

\section{Overview of hyperactivity/impulsivity through a meta-analysis}

In terms of the outcome of hyperactivity/impulsivity, the overall effect showed a statistically significant association with atopic diseases ( $95 \% \mathrm{Cl}$ : $0.23-0.79$; Fig. 1c). Substantial to considerable heterogeneity was noted ( $I^{2}$ value: $\left.86 \%\right)$. The funnel plot (Fig. $\left.1 \mathrm{~d}\right)$ and Egger's test (Figure $\left.S 1 ; p=0.15\right)$ showed no significant publication bias.

\section{Overview of inattention through a meta-analysis}

The overall effect of the outcome of inattention showed a significant and positive correlation with atopic diseases (95\% Cl: 0.3-0.75; Fig. 1e). Different from the outcome of hyperactivity/impulsivity, substantial heterogeneity $\left(I^{2}=68 \%\right)$ was observed for the outcome of inattention. The funnel plot (Fig. $\left.1 f\right)$ and Egger's test (Figure S2; $=0.79$ ) showed no statistically significant publication bias.

\section{Atopic group and a healthy control group}

Two of the studies included an atopic group and a healthy control group to examine total ADHD symptoms, hyperactivity/impulsivity, and inattention. Both studies reported a significant and positive correlation between atopy and severity of total ADHD symptoms, hyperactivity/impulsivity, and inattention, with 95\% Cls of $0.57-0.89$ (Fig. 2a), 0.55-1.65 (Fig. 2b), and 0.23-1.14 (Fig. 2c), respectively.

\section{Atopic group and a nonatopic control group}

Six, three, and two studies included an atopic group and a nonatopic control group to examine the outcome of total ADHD symptoms, hyperactivity/impulsivity, and inattention, respectively. Six studies investigating ADHD symptoms showed a statistically significant association, with a $95 \% \mathrm{Cl}$ of 0.09-0.41 (Fig. 2a). Three and two studies focusing on hyperactivity/impulsivity and inattention demonstrated no statistically significant correlation with atopic diseases, with a $95 \% \mathrm{Cl}$ of $-0.3-0.84$ (Fig. 2b) and $-4.53-5.56$, respectively, with considerable heterogeneity $\left(\mathrm{I}^{2}=92 \%\right.$; Fig. $\left.2 \mathrm{c}\right)$.

\section{Pure atopic group with a healthy control group}

Four studies included a pure atopic group and a healthy control group to examine the outcomes of total ADHD symptoms, hyperactivity/impulsivity, and inattention. Four studies investigating total ADHD symptoms, hyperactivity/impulsivity, and inattention exhibited a statistically significant association, with 95\% Cls of $0.06-0.57$ (Fig. 2a), 0.11-0.68 (Fig. 2b), and 0.13-0.73 (Fig. 2c).

\section{Subgroup analysis of different types of atopic diseases}


A total of six, five, and three studies examined the association between total ADHD symptoms and atopic dermatitis, allergic rhinitis, and asthma, respectively. Furthermore, four, five, and two studies evaluated the association between hyperactivity/impulsivity and dermatitis, allergic rhinitis, and asthma, respectively. Three, five, and two studies examined the association between inattention and atopic dermatitis, allergic rhinitis, and asthma, respectively.

A significant association was observed between atopic dermatitis and total ADHD symptoms and hyperactivity/impulsivity, with low to moderate heterogeneity $\left(\mathrm{I}^{2}=0-59 \%\right.$; Fig. 3a). A significant association was noted between allergic rhinitis and total ADHD symptoms, hyperactivity/impulsivity, and inattention, with moderate to substantial heterogeneity $\left(I^{2}=59-91 \%\right.$; Fig. 3b). Furthermore, a significant association was observed between asthma and only total ADHD symptoms, with low to substantial heterogeneity $\left(I^{2}=0-68 \%\right.$; Fig. 3c).

We observed decreased heterogeneity among subgroups categorized according to their exclusion criteria related to a previous ADHD diagnosis. However, in subgroups were categorized according to the types of atopic diseases, only the atopic dermatitis subgroup showed low to moderate heterogeneity for the outcome of hyperactivity/impulsivity and inattention $\left(1^{2}=0-59 \%\right)$, whereas allergic rhinitis and asthma subgroups both showed low to considerable heterogeneity. In terms of the study design, low to substantial heterogeneity was observed in case-control studies $\left(\mathrm{I}^{2}=0 \%-72 \%\right)$; however, higher heterogeneity than that in the overall meta-analysis was observed in cross-sectional studies $\left(I^{2}=77 \%-96 \%\right)$ for all outcomes (Appendices $\left.E-G\right)$.

\section{Discussion}

The results of our study indicated that atopic diseases were related to not only increased odds of ADHD but also the severity of ADHD symptoms. Total ADHD symptoms, hyperactivity/impulsivity, and inattention were all significantly associated with atopic diseases. The results of the subgroup analysis indicated that children with subthreshold ADHD in the atopic disease groups had increased severity of ADHD symptoms, including total ADHD symptoms, hyperactivity/impulsivity, and inattention, and atopic dermatitis and allergic rhinitis were significantly associated with ADHD symptoms.

Although we included a small number of studies, these studies in total included more than 20,000 participants. In addition, this is the first systematic review and meta-analysis to investigate not only the association of atopic diseases with the severity of ADHD symptoms but also the presentation of ADHD symptoms in children with atopic diseases with normal development. The results of both the qualitative systematic review and meta-analysis tended to demonstrate higher severity of total ADHD symptoms and inattention in participants with atopic diseases, and the meta-analysis showed a significant association between atopic diseases and hyperactivity-impulsivity severity although qualitative synthesis showed relatively inconsistent outcome. Three studies that adopted the computerized CAT to assess attention deficits also demonstrated similar results, thus supporting our hypothesis. However, our qualitative systematic review and meta-analysis exhibited inconsistency in outcomes and considerable heterogeneity.

We divided studies into the following subgroups based on their inclusion and exclusion criteria: atopic group and a healthy control group, atopic group and a nonatopic control group, pure atopic group and a healthy control group. These three subgroups exhibited distinct results in terms of the association between atopic diseases and the severity of total ADHD symptoms, hyperactivity/impulsivity, and inattention. The subgroups of "atopic group and a healthy control group" and "pure atopic group and healthy control group" showed a significant association between atopic diseases and the severity of total ADHD symptoms, hyperactivity/impulsivity, and inattention. However, the subgroup "atopic group and a nonatopic control group" showed a significant association between atopic diseases and only total ADHD symptoms, with low to considerable heterogeneity, despite the inclusion of a small number of studies $\left(\mathrm{I}^{2}=45-\right.$ $92 \%)$. The subgroup analysis of different types of atopic diseases showed that atopic dermatitis was significantly and positively correlated with the severity of total ADHD symptoms and hyperactivity/impulsivity, with low to moderate heterogeneity $\left(1^{2}=0-59 \%\right)$. Allergic rhinitis was significantly associated with the severity of total ADHD symptoms, hyperactivity/impulsivity, and inattention, with moderate to considerable heterogeneity $\left(I^{2}=59-91 \%\right)$. Asthma was significantly associated only with the severity of total ADHD symptoms, with low to substantial heterogeneity $\left(I^{2}=0-68 \%\right)$.

This inconsistency in heterogeneity can be attributed to differences in participants' sex and mean age and the inclusion and exclusion criteria of related studies. A previous study reported a higher male to female ratio for hyperactivity but an equal male to female ratio for inattention ${ }^{33}$. This study also indicated that the distribution of sex differences within the severity of symptoms varied between children without ADHD and children with ADHD. The differences in the clinical course of participants can also result in these inconsistencies. Hyperactivity/impulsivity is usually observed from 4 years of age, peaks in severity at approximately 7 to 8 years, and then declines later, whereas inattention is not apparent until 8-9 years of age ${ }^{34}$. In this study, we observed a significantly decreased heterogeneity in the subgroups "atopic group and a healthy control group" and "pure atopic group and a healthy control group," indicating that inconsistent inclusion and exclusion criteria for ADHD may have been the source of heterogeneity in our study. Moreover, the lack of standard inclusion and exclusion criteria for not only ADHD but also other neuropsychiatric disorders or developmental delays in studies from which the subgroup "atopic group and a nonatopic control group" were formed may be responsible for the high heterogeneity in our study (other subgroups had strictly defined exclusion criteria for confounding factors). Furthermore, our results suggested that children with atopic diseases but without developmental disorders had a higher risk of more severe ADHD symptoms than did control groups, indicating a more consistent result for inattention than hyperactivity/impulsivity. The subgroup "pure atopic group and a healthy control group," which included both atopic and control groups and excluded patients with ADHD, showed a statistically significant association between atopic diseases and the severity of both hyperactivity/impulsivity and inattention. This result suggested that children with subthreshold ADHD and atopic diseases still had an increased severity of ADHD symptoms. The subgroup "atopic group and a healthy control group," which consisted of an atopic group including patients with ADHD and a control group excluding patients with ADHD, had similar results to the aforementioned subgroup.

We also observed low to considerable heterogeneity in the subgroup analysis of different types of atopic diseases. Asthma had a significant association only with the severity of total ADHD symptoms. Considering that previous studies have reported that children with asthma had an increased risk of developing severe ADHD symptoms $18,21,35$, this result may be attributed to the small number of included studies $(n=3)$. The results of the subgroup analysis of different types of atopic diseases indicated that all atopic diseases were significantly associated with the severity of total ADHD symptoms; however, inconsistent 
heterogeneity was observed in the association between atopic diseases and the severity of hyperactivity/impulsivity and inattention. These findings suggest that different types of atopic diseases may have distinct interactions with ADHD symptoms, although our results demonstrated that any type of atopic disease was associated with the severity of ADHD symptoms.

Although the causal relationship and mechanism underlying the association between atopic diseases and ADHD remain unclear, many studies have provided several hypotheses ${ }^{36}$ ) (Figure S6). One of the more commonly accepted hypotheses is that atopic diseases induce inflammation, including Th1, Th2, and Th17 immune responses, which lead to the downstream hypersecretion of IgE ${ }^{37-39}$ (Figure S7). These inflammatory factors may affect the neuroactivity of the prefrontal cortex (PFC) and anterior cingulate cortex (ACC) that have been reported to be strongly associated with ADHD pathology $40-42$. This process affects the maturation of the PFC and ACC, which usually occurs in early life when the brain is undergoing profound changes and is important for the development of cognitive function ${ }^{43}$. In addition to the direct effect, cytokines may indirectly affect these brain areas by disturbing the hypothalamicpituitary-adrenal axis (HPA) axis ${ }^{44}$, altering the central metabolism of neurotransmitters including norepinephrine and dopamine ${ }^{41,45}$.

In addition to neuroimmunological pathways, psychological mechanisms should also be considered. Atopic diseases cause psychological stress in not only patients but also their main caregivers since early childhood when the onset of atopic diseases occurs ${ }^{46,47}$. An unsatisfactory parent-child relationship characterized by overprotection, anxiety, low support, and poor sleep quality can lead to a decline in psychosocial and cognitive performance due to tiredness; emotional problems were reported to be associated with negative outcomes in a previous study ${ }^{48}$. Although the relationship between these effects and brain development in early life has not yet been well studied, stress in early childhood is believed to affect the balance between neurotransmitters and neuroendocrine systems, including norepinephrine, dopamine, and the HPA axis ${ }^{44,49}$. This eventually resulted in increased vulnerability to psychological diseases, such as ADHD, because of altered neuropsychologic pathways leading to unsuccessful brain development and maturation 50 .

An increased risk of the development and progression of atopic diseases was observed in children with ADHD because atopic diseases are attributed to stress

51. Although these mechanisms were obscure, studies have found that stress may induce deficits in skin barriers, and a similar inflammatory cascade with atopy-associated immune responses was observed in patients with atopic diseases; some patients exhibited an increased tendency to exhibit Th1 responses

52 . These findings indicate that stress can exacerbate atopic diseases. ADHD was reported to be related to psychosocial stress because poor family support, school performance, and peer relationships can all be the sources of stress ${ }^{53}$. Therefore, ADHD-related stress can exacerbate atopic diseases. Recently, genetic factors and prenatal stress have been indicated as common risk factors for atopic diseases and ADHD. Although few studies have evaluated genetic susceptibility and other associated interaction factors leading to epigenetic reactions ${ }^{54,55}$, a twin study supported the hypothesis that common genetic factors between atopy and ADHD exist ${ }^{56}$. Moreover, studies reporting a relationship between maternal stress and symptoms of atopic diseases and ADHD have indicated that dysregulation of the HPA axis results in delayed brain development and a shift in Th1/Th2 balance, resulting in an atopic disease-prone immune profile ${ }^{57,58}$.

Previous systematic reviews and meta-analyses had discussed about increased risk of diagnosed ADHD in atopic group; however, the evidence of whether atopic diseases associated with increased severity of ADHD symptoms in participants with subthreshold ADHD remained unclear. This association could be observed in the subgroup "pure atopic group and a healthy control group" in the present study, provided an evidence that atopic diseases are associated with "spectrum of ADHD symptom severity", the term which we quoted following a previous study to explain how atopic diseases affect ADHD symptoms ${ }^{59}$, and this association existed in subthreshold ADHD group in our result as well.

\section{Limitations}

This study has several limitations that should be considered. First, although more than 20,000 participants were included, the outcome of inattention was examined in only 1593 participants, which may reduce the strength of evidence. Second, Atopic diseases were diagnosed based on physicians' decisions or by using some questionnaires in the included studies; these might have caused heterogeneity. Third, we chose to combine scores of hyperactivity/impulsivity and inattention as the primary outcome, and this method has been used in several studies ${ }^{60}$. However, potential systematic errors may still occur. Finally, differences in exclusion criteria, including the exclusion of patients with ADHD and other neuropsychiatric disorders and development problems, caused significant heterogeneity in our study.

To minimize the effect of those limitations, we conducted subgroup analyses to assess the effects of potential confounding factors, namely different types of atopic diseases, exclusion criteria, and study design; this considerably reduced heterogeneity in most subgroup analyses, except in the subgroup analysis of different study designs. Therefore, standardized and more strictly defined exclusion and inclusion criteria should be included in future studies. Moreover, additional studies investigating the relationship between different types of atopic diseases and ADHD symptoms should be conducted because we could not conduct a complete subgroup analysis of different atopic diseases owing to the limited number of studies.

\section{Conclusion}

Our study results indicated that atopic diseases not only increased the odds of ADHD but also were associated with more severe ADHD symptoms. We observed increased severity of ADHD symptoms in children with atopic diseases with normal development after the exclusion of participants with previously diagnosed ADHD, indicating that atopic diseases may also associated with spectrum of ADHD symptom severity in participants with subthreshold ADHD, which was never been investigated in previous researches. According to the results of this study, while treating children with ADHD, clinicians should consider the possibility of comorbid atopic diseases. However, the comorbidity of ADHD should be considered when treating children with atopic diseases. Moreover, clinicians should be aware of the increased severity of ADHD symptoms in children with atopic diseases. Additional studies including more strictly defined 
criteria, studies investigating the mechanism underlying this association, and randomized controlled trials of related therapeutic strategies should be conducted.

\section{Methods}

This systematic review and meta-analysis was conducted in accordance with the Preferred Reporting Items for Systematic Reviews and Meta-Analyses (PRISMA) guidelines ${ }^{61}$. Related checklists are provided in the Supplementary Materials. Two researchers searched for and pooled longitudinal studies examining atopic diseases and ADHD symptom severity to examine the association between them.

\section{Eligibility criteria for study selection}

To reduce selection bias, we defined eligibility criteria before the inclusion of studies. We included the following studies: (1) observational studies investigating the association between one of the three major types of atopic diseases (i.e., asthma, eczema, and allergic rhinitis) and the severity of ADHD symptoms, irrespective of whether they included patients with ADHD in the experimental group; (2) studies recruiting children and adolescents; (3) studies including any of the three atopic diseases as the exposure variable and ADHD symptom severity (scores of a behavior rating scale) as the outcome variable; (4) studies investigating the severity of ADHD symptoms in patients with at least one type of atopic disease by using any type of assessment method; (5) studies including a matched or an unmatched control group for comparison with the exposed group; and (6) cross-sectional, case-control, or cohort studies. The following studies were excluded: (1) studies that did not provide adequate information regarding the relationship between atopic diseases and ADHD symptom severity, including the crude data of exposed cases and the outcome of the association between at least one type of atopic disease and the severity of hyperactivity/impulsivity, inattention, and/or total ADHD symptoms (hyperactivity/impulsivity + inattention) determined on the basis of the scores of a behavior rating scale; (2) studies including only outcomes measured after interventions or those not including a separate outcome of total ADHD symptoms, hyperactivity/impulsivity, and inattention; (3) studies using the same database in different published articles (studies with longer follow-up periods and higher quality, which were classified as included(see 'Table S2 in the Supplementary Materials') were included); and (4) studies whose full texts were not available or those for which only abstracts or editorial materials (i.e., comments, responses, and letters without original data) were available.

\section{Search strategy and study selection}

Two authors performed a literature search on PubMed, Embase, and Cochrane Library for studies published up to January 27, 2021. The following search terms were combined and adjusted to fulfill the demand of the database.

- "Atopic eczema" [MeSH] OR "atopic dermatitis" [MeSH] OR "asthma" [MeSH] OR "allergic rhinitis" [MeSH]

- "Psychiatric disorder" [MeSH] OR "ADHD" [MeSH] OR "attention deficit and hyperactivity disorder" [MeSH] OR "hyperactivity" [MeSH] OR "inattention" [MeSH] OR "mental health" [MeSH] OR "behavior problem" [MeSH]

- "Preschool children" OR "preschooler" OR "children" OR "adolescent" OR "toddler"

A three-step screening strategy was adopted. In the title screening step, studies that met the inclusion criteria and were not letters or replies were included. In the abstract screening step, studies that were original research and included relevant control groups were included. In the full-text screening step, studies for which full texts and data were available and those that did not meet the exclusion criteria were finally included. A third author resolved any disagreement between the two authors in terms of the eligibility and inclusion of studies through discussion.

\section{Data extraction}

By using a customized data form, the first author extracted the following information from eligible studies: study title, study design, study characteristics (country, composition of participants, and outcome assessment scales used), and assessment methods and criteria for diagnosing atopic diseases and ADHD. Subsequently, the second author reviewed the extracted data. Any disagreement regarding data extraction was resolved by the third author through discussion. If required, data were calculated from the available data of included studies (see 'Data abstraction for the meta-analysis'). The main outcome variables were the scores of the behavior rating scales used to evaluate hyperactivity/impulsivity and inattention in the atopic disease and control groups. Although the included studies used different outcome scales, they were all based on the Diagnostic and Statistical Manual of Mental Disorders, 4th Edition (DSM-IV) criteria. In addition, to minimize the potential confounding effects, we analyzed standardized data. Because of the limited availability of studies, we combined the three types of atopic diseases in the meta-analysis and conducted a subgroup analysis. The authors individually recorded abstracted data in Microsoft Excel.

\section{Data abstraction for the meta-analysis}

The relationship between one of the three main types of atopic diseases with the severity of hyperactivity/impulsivity, inattention, or total ADHD symptoms was independently investigated. To exclude confounding factors, any study including outcomes measured after interventions were excluded. For each study, the relative weight of outcome data to the whole data set was calculated using the generic inverse variance method along with the $95 \%$ confidence interval $(95 \% \mathrm{Cl})$ by using Rstudio software, Version 1.2.5042Rstudio ${ }^{62}$. The random effects model with the Hartung-Knapp-Sidik-Jonkman method was used to determine the estimated variance for pooling effect sizes in our meta-analysis. The $\mathrm{I}^{2}$ value was calculated to assess statistical heterogeneity, and this value represents the total variance of pooled data explained by the heterogeneity. According to the Cochrane handbook for systematic reviews of interventions, the $\mathrm{I}^{2}$ values of $0-40 \%, 30-60 \%, 50-90 \%$, and $75-100 \%$ indicated low, moderate, substantial, and considerable heterogeneity ${ }^{63}$. We used a funnel plot to assess the potential publication bias. 
For the outcome "severity of total ADHD symptoms," we combined data on the "severity of hyperactivity/impulsivity" and "severity of inattention" from several studies to measure total ADHD symptoms and conducted a multistep calculation: we obtained the average of the mean scores of hyperactivity/impulsivity and inattention as a combined mean and divided it by the mean scores of hyperactivity/impulsivity or inattention reported in each study. Subsequently, we multiplied the data with the original standard deviation of the scores of hyperactivity/impulsivity or inattention to obtain the combined standard deviation.

For studies including a subgroup analysis, we pooled effect sizes two times. First, we combined subgroups within studies to pool effect sizes and calculated 95\% Cls and standard errors. Subsequently, we included the calculated standard errors into our meta-analysis and pooled effect sizes a second time.

\section{Sensitivity analysis}

To assess the strength of the association between atopic diseases and ADHD in different scenarios, we performed a subgroup analysis by using a mixedeffects model. We divided included studies into groups based on their study design, exclusion criteria for previous ADHD diagnosis, and atopic disease types to perform the subgroup analysis. Detailed information on the risk of bias assessment could be found in Table S2 in the Supplementary Materials

\section{Subgroup analysis of exclusion criteria for those with a previous ADHD diagnosis}

We categorized studies into groups based on whether their experimental or control group included children with ADHD. Theoretically, this categorization would yield four groups: experimental and control groups both including children with ADHD, an experimental group excluding children with ADHD and a control group including children with ADHD, an experimental group including children with ADHD and a control group excluding children with ADHD, and experimental and control groups both excluding children with ADHD. However, none of the included studies had a design wherein the experimental group excluded children with ADHD and the control group included children with ADHD. Thus, we included only the remaining three subgroups. To easily explain the outcome, we named the experimental groups including and excluding children with ADHD as the atopic and pure atopic groups, respectively, and the control group including or excluding ADHD were named the nonatopic or healthy control groups, respectively.

\section{Declarations}

- Ethics approval and consent to participate

- Not applicable.

- Consent for publication

- Not applicable.

- Availability of data and materials

The datasets used and/or analysed during the current study are available from the corresponding author on reasonable request.

- Competing interests

- The authors declare that they no conflicts of interest with respect to this manuscript.

- Funding

- This research did not receive any specific grant from funding agencies in the public, commercial, or not-for-profit sectors.

- Acknowledgements

We would like to acknowledge Yi-No Kang for his help and useful suggestions related to statistical measurements. This manuscript was edited by Wallace Academic Editing.

\section{Data Availability}

The datasets generated during and/or analysed during the current study are available from the corresponding author on reasonable request.

\section{Authors' contributions}

- Conceived and designed the experiments: Yu-chieh Chuang, Yu-Jui Huang, Yang-Ching Chen

- Analyzed the data: Yu-Chieh Chuang, Liang-Jen Wang, Yang-Ching Chen

- Wrote the paper: Yu-Chieh Chuang, Yu-Jui Huang, Wei-Lieh Huang

- Data acquisition, analysis and interpretation; manuscript drafting, editing and submission: Wei-Lieh Huang, Ching-Yun, Wang, Ho-Chang Kuo

- Abstracts review, evaluation of inclusion criteria and bias analysis: Wei-Lieh Huang, Ching-Yun, Wang, Ho-Chang Kuo

\section{References}


1 Worldwide variation in prevalence of symptoms of asthma, allergic rhinoconjunctivitis, and atopic eczema: ISAAC. The International Study of Asthma and Allergies in Childhood (ISAAC) Steering Committee. Lancet 351, 1225-1232 (1998).

2 Asher, M. I. et al. Worldwide time trends in the prevalence of symptoms of asthma, allergic rhinoconjunctivitis, and eczema in childhood: ISAAC Phases One and Three repeat multicountry cross-sectional surveys. Lancet 368, 733-743, doi:10.1016/s0140-6736(06)69283-0 (2006).

3 Schmitt, J. et al. Infant eczema, infant sleeping problems, and mental health at 10 years of age: the prospective birth cohort study LISAplus. Allergy 66, 404411, doi:10.1111/j.1398-9995.2010.02487.x (2011).

4 Stanescu, S., Kirby, S. E., Thomas, M., Yardley, L. \& Ainsworth, B. A systematic review of psychological, physical health factors, and quality of life in adult asthma. NPJ Prim Care Respir Med 29, 37, doi:10.1038/s41533-019-0149-3 (2019).

5 Ferrante, G. \& La Grutta, S. The Burden of Pediatric Asthma. Front Pediatr 6, 186, doi:10.3389/fped.2018.00186 (2018).

6 Schmitt, J. et al. Increased attention-deficit/hyperactivity symptoms in atopic dermatitis are associated with history of antihistamine use. Allergy 73, 615626, doi:10.1111/all.13326 (2018).

7 Hill, M. K., Kheirandish Pishkenari, A., Braunberger, T. L., Armstrong, A. W. \& Dunnick, C. A. Recent trends in disease severity and quality of life instruments for patients with atopic dermatitis: A systematic review. J Am Acad Dermatol 75, 906-917, doi:10.1016/j.jaad.2016.07.002 (2016).

8 O'Connell, E. J. The burden of atopy and asthma in children. Allergy 59 Suppl 78, 7-11, doi:10.1111/j.1398-9995.2004.00563.x (2004).

9 Polanczyk, G. V., Willcutt, E. G., Salum, G. A., Kieling, C. \& Rohde, L. A. ADHD prevalence estimates across three decades: an updated systematic review and meta-regression analysis. Int J Epidemio/ 43, 434-442, doi:10.1093/ije/dyt261 (2014).

10 Hinshaw, S. P. Attention Deficit Hyperactivity Disorder (ADHD): Controversy, Developmental Mechanisms, and Multiple Levels of Analysis. Annu Rev Clin Psychol 14, 291-316, doi:10.1146/annurev-clinpsy-050817-084917 (2018).

11 Bozhilova, N. S., Michelini, G., Kuntsi, J. \& Asherson, P. Mind wandering perspective on attention-deficit/hyperactivity disorder. Neurosci Biobehav Rev 92 , 464-476, doi:10.1016/j.neubiorev.2018.07.010 (2018).

12 Fayyad, J. et al. Cross-national prevalence and correlates of adult attention-deficit hyperactivity disorder. Br J Psychiatry 190, 402-409, doi:10.1192/bjp.bp.106.034389 (2007).

13 Barkley, R. A., Fischer, M., Smallish, L. \& Fletcher, K. The persistence of attention-deficit/hyperactivity disorder into young adulthood as a function of reporting source and definition of disorder. J Abnorm Psychol 111, 279-289 (2002).

14 Pelham, W. E. et al. The long-term financial outcome of children diagnosed with ADHD. J Consult Clin Psycho/ 88, 160-171, doi:10.1037/ccp0000461 (2020).

15 McGee, R., Stanton, W. R. \& Sears, M. R. Allergic disorders and attention deficit disorder in children. J Abnorm Child Psycho/ 21, 79-88, doi:10.1007/bf00910490 (1993).

16 Kaas, T. H. et al. Association between childhood asthma and attention deficit hyperactivity or autism spectrum disorders: A systematic review with metaanalysis. Clin Exp Allergy 51, 228-252, doi:10.1111/cea.13750 (2021).

17 Deckert, S., Kopkow, C. \& Schmitt, J. Nonallergic comorbidities of atopic eczema: an overview of systematic reviews. Allergy 69, 37-45, doi:10.1111/all.12246 (2014).

18 Borschuk, A. P., Rodweller, C. \& Salorio, C. F. The influence of comorbid asthma on the severity of symptoms in children with attention-deficit hyperactivity disorder. J Asthma 55, 66-72, doi:10.1080/02770903.2017.1306549 (2018).

19 Schmitt, J., Apfelbacher, C., Heinrich, J., Weidinger, S. \& Romanos, M. [Association of atopic eczema and attention-deficit/hyperactivity disorder - metaanalysis of epidemiologic studies]. Z Kinder Jugendpsychiatr Psychother 41, 35-42; quiz 42-34, doi:10.1024/1422-4917/a000208 (2013).

20 Schans, J. V., Çiçek, R., de Vries, T. W., Hak, E. \& Hoekstra, P. J. Association of atopic diseases and attention-deficit/hyperactivity disorder: A systematic review and meta-analyses. Neurosci Biobehav Rev 74, 139-148, doi:10.1016/j.neubiorev.2017.01.011 (2017).

21 Schans, J. v. d., Çiçek, R., de Vries, T. W., Hak, E. \& Hoekstra, P. J. Association of atopic diseases and attention-deficit/hyperactivity disorder: A systematic review and meta-analyses. Neuroscience \& Biobehavioral Reviews 74, 139-148, doi:https://doi.org/10.1016/j.neubiorev.2017.01.011 (2017).

22 Yang, M. T. et al. Attention-deficit/hyperactivity disorder-related symptoms improved with allergic rhinitis treatment in children. American Journal of Rhinology and Allergy 30, 209-214, doi:10.2500/ajra.2016.30.4301 (2016).

23 Tajdini, M. et al. Associations of Behavioral Disorders with Asthma in Iranian Children. Iran J Allergy Asthma Immunol 18, 340-345, doi:10.18502/ijaai.v18i3.1127 (2019). 
$24 \mathrm{Kim}, \mathrm{D}$. K. et al. Treatment of allergic rhinitis is associated with improved attention performance in children: the Allergic Rhinitis Cohort Study for Kids (ARCO-Kids). PLoS One 9, e109145, doi:10.1371/journal.pone.0109145 (2014).

25 Hammer-Helmich, L. et al. Mental health associations with eczema, asthma and hay fever in children: a cross-sectional survey. BMJ Open 6, e012637, doi:10.1136/bmjopen-2016-012637 (2016).

26 Kuniyoshi, Y. et al. Severity of eczema and mental health problems in Japanese schoolchildren: The ToMMo Child Health Study. Allergol Int 67, 481-486, doi:10.1016/j.alit.2018.02.009 (2018).

27 Wan, J., Takeshita, J., Shin, D. B. \& Gelfand, J. M. Mental health impairment among children with atopic dermatitis: A United States population-based crosssectional study of the 2013-2017 National Health Interview Survey. J Am Acad Dermato/ 82, 1368-1375, doi:10.1016/j.jaad.2019.10.019 (2020).

28 Edvinsson Sollander, S. et al. Asthma and allergies correlate with mental health problems in preschool children. Acta Paediatr, doi:10.1111/apa.15709 (2020).

29 He, J. P., Burstein, M., Schmitz, A. \& Merikangas, K. R. The Strengths and Difficulties Questionnaire (SDQ): the factor structure and scale validation in U.S. adolescents. J Abnorm Child Psychol 41, 583-595, doi:10.1007/s10802-012-9696-6 (2013).

30 Algorta, G. P., Dodd, A. L., Stringaris, A. \& Youngstrom, E. A. Diagnostic efficiency of the SDQ for parents to identify ADHD in the UK: a ROC analysis. Eur Child Adolesc Psychiatry 25, 949-957, doi:10.1007/s00787-015-0815-0 (2016).

31 Vugteveen, J., De Bildt, A., Hartman, C. A. \& Timmerman, M. E. Using the Dutch multi-informant Strengths and Difficulties Questionnaire (SDQ) to predict adolescent psychiatric diagnoses. Eur Child Adolesc Psychiatry 27, 1347-1359, doi:10.1007/s00787-018-1127-y (2018).

32 Camfferman, D. et al. Eczema, sleep, and behavior in children. J Clin Sleep Med 6, 581-588 (2010).

33 Mowlem, F. D. et al. Sex differences in predicting ADHD clinical diagnosis and pharmacological treatment. Eur Child Adolesc Psychiatry 28, 481-489, doi:10.1007/s00787-018-1211-3 (2019).

34 Applegate, B. et al. Validity of the age-of-onset criterion for ADHD: a report from the DSM-IV field trials. J Am Acad Child Adolesc Psychiatry 36, 1211-1221 (1997).

$35 \mathrm{Kaas}$, T. H. et al. Association between childhood asthma and attention deficit hyperactivity or autism spectrum disorders: A systematic review with metaanalysis. Clin Exp Allergy, doi:10.1111/cea.13750 (2020).

36 Buske-Kirschbaum, A. et al. Psychoendocrine and psychoneuroimmunological mechanisms in the comorbidity of atopic eczema and attention deficit/hyperactivity disorder. Psychoneuroendocrinology 38, 12-23, doi:10.1016/j.psyneuen.2012.09.017 (2013).

37 Czarnowicki, T. et al. Early pediatric atopic dermatitis shows only a cutaneous lymphocyte antigen (CLA)(+) TH2/TH1 cell imbalance, whereas adults acquire CLA(+) TH22/TC22 cell subsets. J Allergy Clin Immuno/ 136, 941-951.e943, doi:10.1016/j.jaci.2015.05.049 (2015).

38 Czarnowicki, T. et al. Evolution of pathologic T-cell subsets in patients with atopic dermatitis from infancy to adulthood. J Allergy Clin Immuno/ 145, 215228, doi:10.1016/j.jaci.2019.09.031 (2020).

39 Looman, K. I. M. et al. Associations of Th2, Th17, Treg cells, and IgA(+) memory B cells with atopic disease in children: The Generation R Study. Allergy 75, 178-187, doi:10.1111/all.14010 (2020).

40 Puiu, A. A. et al. Impulsive aggression and response inhibition in attention-deficit/hyperactivity disorder and disruptive behavioral disorders: Findings from a systematic review. Neurosci Biobehav Rev 90, 231-246, doi:10.1016/j.neubiorev.2018.04.016 (2018).

41 Xing, B., Li, Y. C. \& Gao, W. J. Norepinephrine versus dopamine and their interaction in modulating synaptic function in the prefrontal cortex. Brain Res 1641 , 217-233, doi:10.1016/j.brainres.2016.01.005 (2016).

$42 \mathrm{Kim}, \mathrm{J}$. I. et al. Interaction between DRD2 and lead exposure on the cortical thickness of the frontal lobe in youth with attention-deficit/hyperactivity disorder. Prog Neuropsychopharmacol Biol Psychiatry 82, 169-176, doi:10.1016/j.pnpbp.2017.11.018 (2018).

43 Hiser, J. \& Koenigs, M. The Multifaceted Role of the Ventromedial Prefrontal Cortex in Emotion, Decision Making, Social Cognition, and Psychopathology. Biol Psychiatry 83, 638-647, doi:10.1016/j.biopsych.2017.10.030 (2018).

44 Buske-Kirschbaum, A. et al. Altered hypothalamus-pituitary-adrenal axis function: A relevant factor in the comorbidity of atopic eczema and attention deficit/hyperactivity disorder? Psychoneuroendocrinology 105, 178-186, doi:10.1016/j.psyneuen.2018.12.005 (2019).

45 Park, G., Jung, Y. S., Park, M. K., Yang, C. H. \& Kim, Y. U. Melatonin inhibits attention-deficit/hyperactivity disorder caused by atopic dermatitis-induced psychological stress in an NC/Nga atopic-like mouse model. Sci Rep 8, 14981, doi:10.1038/s41598-018-33317-x (2018).

46 Xu, Y. C., Wang, J. P., Zhu, W. J. \& Li, P. Childhood atopic dermatitis as a precursor for developing attention deficit/hyperactivity disorder. Int J Immunopathol Pharmaco/ 34, 2058738420962902, doi:10.1177/2058738420962902 (2020). 
47 Kuo, H. C., Chang, L. S., Tsai, Z. Y. \& Wang, L. J. Allergic diseases do not impair the cognitive development of children but do damage the mental health of their caregivers. Sci Rep 10, 13854, doi:10.1038/s41598-020-70825-1 (2020).

48 Chamlin, S. L., Frieden, I. J., Williams, M. L. \& Chren, M. M. Effects of atopic dermatitis on young American children and their families. Pediatrics 114, 607611, doi:10.1542/peds.2004-0374 (2004).

49 Nicolaides, N. C., Kyratzi, E., Lamprokostopoulou, A., Chrousos, G. P. \& Charmandari, E. Stress, the stress system and the role of glucocorticoids. Neuroimmunomodulation 22, 6-19, doi:10.1159/000362736 (2015).

50 McCrory, E., De Brito, S. A. \& Viding, E. Research review: the neurobiology and genetics of maltreatment and adversity. J Child Psychol Psychiatry 51, 10791095, doi:10.1111/j.1469-7610.2010.02271.x (2010).

51 Lin, T. K., Zhong, L. \& Santiago, J. L. Association between Stress and the HPA Axis in the Atopic Dermatitis. Int J Mol Sci 18, doi:10.3390/ijms18102131 (2017).

52 Buske-Kirschbaum, A., Gierens, A., Höllig, H. \& Hellhammer, D. H. Stress-induced immunomodulation is altered in patients with atopic dermatitis. $J$ Neuroimmunol 129, 161-167, doi:10.1016/s0165-5728(02)00168-6 (2002).

53 Quinlan, E. B. et al. Psychosocial Stress and Brain Function in Adolescent Psychopathology. Am J Psychiatry 174, 785-794, doi:10.1176/appi.ajp.2017.16040464 (2017).

$54 \mathrm{Lau}, \mathrm{M}$. et al. Loss of STAT6 promotes autoimmune disease and atopy on a susceptible genetic background. J Autoimmun 39, 388-397, doi:10.1016/j.jaut.2012.06.003 (2012).

55 Tsai, S. J. Signal transducer and activator of transcription 6 (STAT6) and attention-deficit hyperactivity disorder: a speculative hypothesis. Med Hypotheses 67, 1342-1344, doi:10.1016/j.mehy.2006.05.019 (2006).

56 Wamboldt, M. Z. et al. Familial association between allergic disorders and depression in adult Finnish twins. Am J Med Genet 96, 146-153, doi:10.1002/(sici)1096-8628(20000403)96:2<146::aid-ajmg4>3.0.co;2-j (2000).

57 Van den Bergh, B. R. H. et al. Prenatal developmental origins of behavior and mental health: The influence of maternal stress in pregnancy. Neurosci Biobehav Rev, doi:10.1016/j.neubiorev.2017.07.003 (2017).

58 Cowell, W. J., Bellinger, D. C., Wright, R. O. \& Wright, R. J. Antenatal active maternal asthma and other atopic disorders is associated with ADHD behaviors among school-aged children. Brain Behav Immun 80, 871-878, doi:10.1016/j.bbi.2019.05.040 (2019).

59 Roigé-Castellví, J. et al. Prenatal and perinatal factors associated with ADHD risk in schoolchildren: EPINED epidemiological study. Eur Child Adolesc Psychiatry, doi:10.1007/s00787-020-01519-2 (2020).

60 Sun, C. K. et al. Therapeutic effects of methylphenidate for attention-deficit/hyperactivity disorder in children with borderline intellectual functioning or intellectual disability: A systematic review and meta-analysis. Sci Rep 9, 15908, doi:10.1038/s41598-019-52205-6 (2019).

61 Moher, D. et al. Preferred reporting items for systematic review and meta-analysis protocols (PRISMA-P) 2015 statement. Syst Rev 4, 1, doi:10.1186/20464053-4-1 (2015).

62 RStudio Team, 2020. RStudio: Integrated Development for R. RStudio, PBC, Boston, MA URL http://www.rstudio.com/.

63 Higgins, J. P. \& Thompson, S. G. Quantifying heterogeneity in a meta-analysis. Stat Med 21, 1539-1558, doi:10.1002/sim.1186 (2002).

64 Yuksel, H., Sogut, A. \& Yilmaz, O. Attention deficit and hyperactivity symptoms in children with asthma. Journal of Asthma 45, 545-547, doi:10.1080/02770900801990016 (2008).

65 Chang, H. Y. et al. Allergic diseases in preschoolers are associated with psychological and behavioural problems. Allergy Asthma Immunol Res 5, 315-321, doi:10.4168/aair.2013.5.5.315 (2013).

66 Goodwin, R. D. et al. Severity and persistence of asthma and mental health: a birth cohort study. Psychol Med 43, 1313-1322, doi:10.1017/S0033291712001754 (2013).

67 Lee, Y. S. et al. Attention deficit hyperactivity disorder like behavioral problems and parenting stress in pediatric allergic rhinitis. Psychiatry Investig 11, 266271, doi:10.4306/pi.2014.11.3.266 (2014).

68 Yang, M. T. et al. Hyperactivity and impulsivity in children with untreated allergic rhinitis: Corroborated by rating scale and continuous performance test. Pediatrics and Neonatology 55, 168-174, doi:10.1016/j.pedneo.2013.09.003 (2014).

69 Catal, F. et al. Psychiatric disorders and symptoms severity in preschool children with atopic eczema. Allergologia et Immunopathologia 44, 120-124, doi:10.1016/j.aller.2015.04.006 (2016). 
70 Strom, M. A., Fishbein, A. B., Paller, A. S. \& Silverberg, J. I. Association between atopic dermatitis and attention deficit hyperactivity disorder in U.S. children and adults. Br J Dermato/ 175, 920-929, doi:10.1111/bjd.14697 (2016).

71 Feng, B. et al. Association of pediatric allergic rhinitis with the ratings of attention-deficit/hyperactivity disorder. Am J Rhinol Allergy 31, 161-167, doi:10.2500/ajra.2017.31.4439 (2017).

72 Abd El-Hamid, Z. B. et al. Impact of allergy on children with attention deficit hyperactivity disorder. Eur Ann Allergy Clin Immuno/ 50, 262-267, doi:10.23822/EurAnnACl.1764-1489.72 (2018).

73 Schmitt, J. et al. Increased attention-deficit/hyperactivity symptoms in atopic dermatitis are associated with history of antihistamine use. Allergy: European Journal of Allergy and Clinical Immunology 73, 615-626, doi:10.1111/all.13326 (2018).

74 L, L. K., Cices, A., Fishbein, A. B. \& Paller, A. S. Neurocognitive function in moderate-severe pediatric atopic dermatitis: A case-control study. Pediatr Dermatol 36, 110-114, doi:10.1111/pde.13710 (2019).

75 Zhou, H., Chen, Z., Zhao, W., Liu, Y. \& Cui, Y. Evaluation of neuropsychiatric comorbidities and their clinical characteristics in Chinese children with asthma using the MINI kid tool. BMC Pediatr 19, 454, doi:10.1186/s12887-019-1834-7 (2019).

76 Feng, L. J., Chen, A. W., Luo, X. Y. \& Wang, H. Increased attention deficit/hyperactivity and oppositional defiance symptoms of 6-12 years old Chinese children with atopic dermatitis. Medicine (Baltimore) 99, e20801, doi:10.1097/MD.0000000000020801 (2020).

77 Guo, M. M., Wang, L. J., Hsu, T. Y., Yang, K. D. \& Kuo, H. C. Peanut Sensitivity and Allergic Rhinitis in Young Children are Associated with Attention-Deficit Hyperactivity Disorder Symptoms in Adolescence. Neuropsychiatr Dis Treat 16, 1349-1357, doi:10.2147/NDT.S232299 (2020).

78 Huang, A. H. et al. Real-world comorbidities of atopic dermatitis in the pediatric ambulatory population in the United States. J Am Acad Dermatol, doi:10.1016/j.jaad.2021.03.016 (2021).

79 Jackson-Cowan, L., Cole, E. F., Silverberg, J. I. \& Lawley, L. P. Childhood atopic dermatitis is associated with cognitive dysfunction: A National Health Interview Survey study from 2008 to 2018. Ann Allergy Asthma Immunol 126, 661-665, doi:10.1016/j.anai.2020.11.008 (2021).

80 Edvinsson Sollander, S. et al. Asthma and allergies correlate with mental health problems in preschool children. Acta Paediatr 110, 1601-1609, doi:10.1111/apa.15709 (2021).

\section{Tables}

Table 1 Studies examining the relationship between atopic diseases and hyperactivity in the qualitative analysis. 


\begin{tabular}{|c|c|c|c|c|c|c|c|}
\hline Study name & Outcome $(95 \% \mathrm{Cl})$ & $\begin{array}{l}\text { Study } \\
\text { design }\end{array}$ & Country/City & Ethnicity & $\begin{array}{l}\text { Number of } \\
\text { participants/ } \\
\text { experimental } \\
\text { group/control group }\end{array}$ & $\begin{array}{l}\text { Age (mean of } \\
\text { the } \\
\text { experimental } \\
\text { group)/sex } \\
\text { (male, \%) }\end{array}$ & $\begin{array}{l}\text { Diagnostic } \\
\text { criteria for ADHD }\end{array}$ \\
\hline $\begin{array}{l}\text { Yuksel et al., } \\
2008^{64}\end{array}$ & $\begin{array}{l}\text { Continuous } \\
\text { data for } \mathrm{HI} \text { and } \mathrm{IN}^{\star}\end{array}$ & $\begin{array}{l}\text { Cross- } \\
\text { sectional }\end{array}$ & $\begin{array}{l}\text { Manisa, } 45020 \\
\text { Turkey }\end{array}$ & Not reported & $100 / 62 / 38$ & $\begin{array}{l}\text { 7-12 years } \\
(9.2) / 57 \%\end{array}$ & DSM-IV \\
\hline $\begin{array}{l}\text { Camfferman } \\
\text { et al., } \\
2010^{32}\end{array}$ & $\begin{array}{l}\text { Continuous } \\
\text { data for } \mathrm{HI}^{\star} \text { and total } \\
\text { ADHD symptoms* }\end{array}$ & $\begin{array}{l}\text { Cross- } \\
\text { sectional }\end{array}$ & $\begin{array}{l}\text { South Australia, } \\
\text { Australia }\end{array}$ & Not reported & $107 / 77 / 30$ & $\begin{array}{l}6-16 \text { years } \\
(9.9) / 46.72 \%\end{array}$ & $\begin{array}{l}\text { Conner's Parent } \\
\text { Rating Scale- } \\
\text { Revised }\end{array}$ \\
\hline $\begin{array}{l}\text { Chang et al., } \\
2013^{65}\end{array}$ & $\begin{array}{l}\text { Continuous data for } \\
\mathrm{HI} \text { and IN }\end{array}$ & $\begin{array}{l}\text { Cross- } \\
\text { sectional }\end{array}$ & $\begin{array}{l}\text { Seoul and } \\
\text { Ilsan and } \\
\text { Gwacheon in } \\
\text { Gyeonggi-do } \\
\text { province in Korea }\end{array}$ & Not reported & 575 & $\begin{array}{l}3-7 \text { years } \\
(4.8) / \\
51.3 \%\end{array}$ & CBCL \\
\hline $\begin{array}{l}\text { Goodwin et } \\
\text { al., } 2013^{66}\end{array}$ & $\begin{array}{l}\text { OR of ADHD in } \\
\text { children with asthma* } \\
\text { (different grades of } \\
\text { severity } \\
\text { [moderate*]/persistent } \\
\text { [remission* and late } \\
\text { onset*]) }\end{array}$ & Cohort & $\begin{array}{l}\text { Perth, Western } \\
\text { Australia }\end{array}$ & Not reported & $\begin{array}{l}2193 / 390 / \\
1803\end{array}$ & $\begin{array}{l}5,8,10,14, \\
\text { and } 17 \text { years/ } \\
62.56 \%\end{array}$ & $\mathrm{CBCL}$ \\
\hline $\begin{array}{l}\text { Kim et al., } \\
2014^{24}\end{array}$ & $\begin{array}{l}\text { Continuous data for } \\
\text { impulsivity and } \\
\text { inattention (divided } \\
\text { attention task }{ }^{\star} \text { ) }\end{array}$ & Cohort & Korea & Not reported & $1036 / 797 / 239$ & $\begin{array}{l}3-16 \text { years } \\
(11.4) / \\
69.88 \%\end{array}$ & $\begin{array}{l}\text { Computerized } \\
\text { comprehensive } \\
\text { attention test }\end{array}$ \\
\hline $\begin{array}{l}\text { Lee et al., } \\
2014^{67}\end{array}$ & $\begin{array}{l}\text { Continuous } \\
\text { data for } \mathrm{HI} \text { and IN* }\end{array}$ & $\begin{array}{l}\text { Cross- } \\
\text { sectional }\end{array}$ & Seoul, Korea & Not reported & $160 / 87 / 73$ & $\begin{array}{l}6-13 \text { years } \\
(8.49) / 39.4 \%\end{array}$ & DSM-IV \\
\hline $\begin{array}{l}\text { Yang et al., } \\
2014^{68}\end{array}$ & $\begin{array}{l}\text { Continuous } \\
\text { data for } \mathrm{HI}^{*} \text { and } \mathrm{IN}^{*}\end{array}$ & $\begin{array}{l}\text { Cross- } \\
\text { sectional }\end{array}$ & Taipei, Taiwan & Not reported & $122 / 93 / 29$ & $\begin{array}{l}6-14 \text { years } \\
(10.78) / 52.2 \%\end{array}$ & DSM-IV-TR \\
\hline $\begin{array}{l}\text { Catal et al., } \\
2016^{69}\end{array}$ & $\begin{array}{l}\text { Continuous data for } \\
\text { total ADHD } \\
\text { symptoms* and } \\
\text { percentage of } \\
\text { psychiatric disorders } \\
\text { determined by ECl-4* }\end{array}$ & $\begin{array}{l}\text { Cross- } \\
\text { sectional }\end{array}$ & $\begin{array}{l}\text { Malatya, } \\
\text { Samsun, Aydın, } \\
\text { Istanbul, Turkey }\end{array}$ & Not reported & $154 / 80 / 74$ & $\begin{array}{l}3-5 \text { years } \\
(4.03) / 51.3 \%\end{array}$ & $\mathrm{ECl}-4$ \\
\hline $\begin{array}{l}\text { Hammer- } \\
\text { Helmich et } \\
\text { al., } 2016^{25}\end{array}$ & 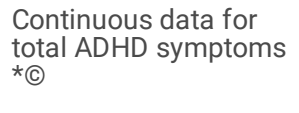 & $\begin{array}{l}\text { Cross- } \\
\text { sectional }\end{array}$ & $\begin{array}{l}\text { Copenhagen, } \\
\text { Denmark }\end{array}$ & Not reported & $\begin{array}{l}9036 / 2433 / \\
6603\end{array}$ & $\begin{array}{l}3-15 \text { years } \\
\text { (NA)/49.5\% }\end{array}$ & SDQ \\
\hline $\begin{array}{l}\text { Strom et al., } \\
2016^{70}\end{array}$ & $\begin{array}{l}\text { OR of } A D D / A D H D \text { in } \\
\text { children with atopic } \\
\text { dermatitis* }\end{array}$ & $\begin{array}{l}\text { Cross- } \\
\text { sectional }\end{array}$ & $\begin{array}{l}\text { U.S. Bureau of } \\
\text { Census }\end{array}$ & Not reported & 180799/17277/163522 & $\begin{array}{l}<18 \text { years } \\
\text { (NA) } / 49.94 \%\end{array}$ & Questionnaire \\
\hline $\begin{array}{l}\text { Yang et al., } \\
2016^{22}\end{array}$ & $\begin{array}{l}\text { Continuous } \\
\text { data for } \mathrm{HI}^{\star} \text { and } \mathrm{IN}^{\star}\end{array}$ & $\begin{array}{l}\text { Case- } \\
\text { control }\end{array}$ & Taipei, Taiwan & Not reported & $99 / 68 / 31$ & $\begin{array}{l}6-14 \text { years } \\
(9.25) / 82.4 \%\end{array}$ & DSM-IV \\
\hline $\begin{array}{l}\text { Feng et al., } \\
2017^{71}\end{array}$ & $\begin{array}{l}\text { Continuous } \\
\text { data for } \mathrm{HI}^{\star} \text { and } \mathrm{IN}^{*}\end{array}$ & $\begin{array}{l}\text { Cross- } \\
\text { sectional }\end{array}$ & Wenzhou, China & Not reported & $643 / 248 / 320$ & $\begin{array}{l}6-12 \text { years } \\
(9.25) / 51.9 \%\end{array}$ & DSM-IV \\
\hline $\begin{array}{l}\text { Lin et al., } \\
2017^{51}\end{array}$ & $\begin{array}{l}\text { OR of ADHD } \\
\text { (inattentive/ } \\
\text { Hyperactive } \\
\text { impulsive/combined) } \\
\text { in children with atopic } \\
\text { dermatitis, asthma, } \\
\text { allergic rhinitis } \\
\text { (fever/active)* }\end{array}$ & $\begin{array}{l}\text { Cross- } \\
\text { sectional }\end{array}$ & Taiwan & Han Chinese & $\begin{array}{l}2896 / 2235 / \\
661\end{array}$ & $\begin{array}{l}9-10 \text { years } \\
(10) / 50.5 \%\end{array}$ & SNAP-IV \\
\hline $\begin{array}{l}\text { Abd El- } \\
\text { Hamid et al., }\end{array}$ & $\begin{array}{l}\text { Prevalence of } \\
\text { different grades of }\end{array}$ & $\begin{array}{l}\text { Case- } \\
\text { control }\end{array}$ & Cairo, Egypt & Not reported & $160 / 100 / 60$ & $\begin{array}{l}6-12 \text { years } \\
(8.54) / 81.25 \%\end{array}$ & DSM-IV \\
\hline
\end{tabular}




\begin{tabular}{|c|c|c|c|c|c|c|c|}
\hline $2018^{72}$ & $\begin{array}{l}\text { ADHD symptoms } \\
\text { (mild, moderate, and } \\
\text { severe) in children } \\
\text { with or without atopic } \\
\text { diseases* }\end{array}$ & & & & & & \\
\hline $\begin{array}{l}\text { Kuniyoshi et } \\
\text { al., } 2018^{26}\end{array}$ & $\begin{array}{l}\text { Continuous data for } \\
\text { total ADHD } \\
\text { symptoms@* }\end{array}$ & $\begin{array}{l}\text { Cross- } \\
\text { sectional }\end{array}$ & $\begin{array}{l}\text { Miyagi } \\
\text { Prefecture, Japan }\end{array}$ & Not reported & $9954 / 1641 / 8313$ & $\begin{array}{l}7-14 \text { years } \\
(10.42) / 49.9 \%\end{array}$ & SDQ \\
\hline $\begin{array}{l}\text { Schmitt et } \\
\text { al., } 2018^{73}\end{array}$ & $\begin{array}{l}\text { Continuous } \\
\text { data for } \mathrm{HI} \text { and } \mathrm{IN}^{\star}\end{array}$ & $\begin{array}{l}\text { Case- } \\
\text { control }\end{array}$ & $\begin{array}{l}\text { Dresden, } \\
\text { Germany }\end{array}$ & Not reported & $89 / 35 / 45$ & $\begin{array}{l}6-12 \text { years } \\
(9.9) / 62.9 \%\end{array}$ & ICD-10 \\
\hline $\begin{array}{l}\text { Cices et al., } \\
2019^{74}\end{array}$ & $\begin{array}{l}\text { Continuous } \\
\text { data for } \mathrm{HI} \text { and } \mathrm{IN}^{*}\end{array}$ & $\begin{array}{l}\text { Case- } \\
\text { control }\end{array}$ & $\begin{array}{l}\text { US, Chicago, } \\
\text { Illinois }\end{array}$ & $\begin{array}{l}\text { Caucasian } \\
(31.43 \%) \\
\text { African } \\
\text { American } \\
(22.86 \%) \\
\text { Hispanic } \\
(20 \%) \\
\text { Asian }(20 \%) \\
\text { Other(5.71\%) }\end{array}$ & $35 / 17 / 18$ & $\begin{array}{l}\text { 6-16 years } \\
(11.07) / 65.7 \%\end{array}$ & $\begin{array}{l}\text { Standardized } \\
\text { Vanderbilt } \\
\text { questionnaires }\end{array}$ \\
\hline $\begin{array}{l}\text { Tajdini et al., } \\
2019^{23}\end{array}$ & $\begin{array}{l}\text { Prevalence of ADHD } \\
\text { in patients with } \\
\text { asthma and controls* }\end{array}$ & $\begin{array}{l}\text { Case- } \\
\text { control }\end{array}$ & Tehran, Iran & Not reported & $171 / 79 / 92$ & $\begin{array}{l}5-11 \text { years } \\
(7.54) / 57 \%\end{array}$ & $\begin{array}{l}\text { Child Symptom } \\
\text { Inventory-4 } \\
\text { (CSI-4) }\end{array}$ \\
\hline $\begin{array}{l}\text { Zhou et al., } \\
2019^{75}\end{array}$ & $\begin{array}{l}\text { Prevalence of ADHD } \\
\text { in patients with } \\
\text { asthma and controls* }\end{array}$ & $\begin{array}{l}\text { Cross- } \\
\text { sectional }\end{array}$ & Guiyang, China & $\operatorname{Han}(77.59 \%)$ & $522 / 261 / 261$ & $\begin{array}{l}6-16 \text { years } \\
(9.35) / 61.69 \%\end{array}$ & $\begin{array}{l}\text { Mini- } \\
\text { International } \\
\text { Neuropsychiatric } \\
\text { Interview for } \\
\text { children and } \\
\text { adolescents }\end{array}$ \\
\hline $\begin{array}{l}\text { Feng et al., } \\
2020^{76}\end{array}$ & $\begin{array}{l}\text { Continuous } \\
\text { data for } \mathrm{HI}^{\star} \text { and IN* }\end{array}$ & $\begin{array}{l}\text { Cross- } \\
\text { sectional }\end{array}$ & Chongqing, China & Not reported & 273/89/184 & $\begin{array}{l}6-12 \text { years } \\
(8.3) / 62.63 \%\end{array}$ & SNAP-IV \\
\hline $\begin{array}{l}\text { Guo et al., } \\
2020^{77}\end{array}$ & $\begin{array}{l}\text { Continuous } \\
\text { data for } H I \text { (AR, } A D \text {, } \\
\text { and asthma) and IN } \\
\text { (AR*, } A D \text {, and } \\
\text { asthma*) }\end{array}$ & Cohort & $\begin{array}{l}\text { Kaohsiung, } \\
\text { Taiwan }\end{array}$ & Not reported & 97 & 6 years $/ 54.6 \%$ & SNAP-IV \\
\hline $\begin{array}{l}\text { Huang et al., } \\
2020^{78}\end{array}$ & $\begin{array}{l}\text { OR of } A D D / A D H D \text { in } \\
\text { children with atopic } \\
\text { dermatitis* }\end{array}$ & $\begin{array}{l}\text { Cross- } \\
\text { sectional }\end{array}$ & $\begin{array}{l}\text { US } \\
\text { Northeast } \\
(17.96 \%) \\
\text { North Central } \\
(19.33 \%) \\
\text { South }(45.83 \%) \\
\text { West }(16.42 \%) \\
\text { Unknown }(0.47 \%)\end{array}$ & Not reported & 203533/86969/116564 & $\begin{array}{l}0-17 \\
\text { years(5.3) } \\
/ 51.74 \%\end{array}$ & ICD-10-CM \\
\hline $\begin{array}{l}\text { Jackson- } \\
\text { Cowan et al., } \\
2020^{79}\end{array}$ & $\begin{array}{l}\text { OR of } A D D / A D H D \text { in } \\
\text { children with atopic } \\
\text { dermatitis* }\end{array}$ & $\begin{array}{l}\text { Cross- } \\
\text { sectional }\end{array}$ & $\begin{array}{l}\text { US } \\
\text { Northeast } \\
(15.73 \%) \\
\text { North Central } \\
(20.27 \%) \\
\text { South (36.21\%) } \\
\text { West (27.78\%) }\end{array}$ & $\begin{array}{l}\text { White } \\
(48.44 \%) \\
\text { Black } \\
(15.38 \%) \\
\text { Hispanic } \\
(27.86 \%) \\
\text { Asian } \\
(6.06 \%) \\
\text { Native } \\
\text { American } \\
(0.97 \%) \\
\text { Other } \\
(1.29 \%)\end{array}$ & 109482/13398/96084 & $\begin{array}{l}2-17 \\
\text { years/51.48\% }\end{array}$ & Questionnaire \\
\hline Kuo et al., & Continuous & $\begin{array}{l}\text { Cross- } \\
\text { sectional }\end{array}$ & $\begin{array}{l}\text { Kaohsiung, } \\
\text { Taiwan }\end{array}$ & Not reported & $191 / 109 / 92$ & (6.59)/54.44\% & SNAP-IV \\
\hline
\end{tabular}


$2020^{47}$ data for $\mathrm{HI}^{*}$ and IN

\begin{tabular}{|c|c|c|c|c|c|c|}
\hline $\begin{array}{l}\text { Sollander et } \\
\text { al., } 2020^{80}\end{array}$ & $\begin{array}{l}\text { OR of ADD/ADHD in } \\
\text { children with atopic } \\
\text { dermatitis* }\end{array}$ & $\begin{array}{l}\text { Cross- } \\
\text { sectional }\end{array}$ & Uppsala, Sweden & Not reported & $4451 / 397 / 4054$ & $\begin{array}{l}3-5 \text { years } \\
(4.34) / 50.42 \%\end{array}$ \\
\hline
\end{tabular}

Abbreviations: ADHD, Attention-Deficit/Hyperactivity Disorder; OR, Odds Ratio; HI, Hyperactivity/Impulsivity; IA, Inattention; DSM-IV, Diagnostic and Statistical Manual of Mental Disorders; GINA 2006, Global Initiative for Asthma, 2006; CBCL, Child Behavior Checklist; ARIA, Allergic Rhinitis and its Impact on Asthma; MAST, multiple-antigen simultaneous test; ECI-4, The Early Childhood Inventory-4; SDQ, Strengths and Difficulties Questionnaire; ICD-10, International Classification of Diseases, Tenth Revision; SCORAD, SCORing Atopic Dermatitis; ISAAC, International Study of Asthma and Allergies in Childhood

(c) Calculated from the available information in the article *Statistically significant

Table 2 Studies examining the relationship between atopic diseases and hyperactivity in the meta-analysis.

\begin{tabular}{|c|c|c|c|c|c|c|c|c|}
\hline Study name & Country & $\begin{array}{l}\text { Study } \\
\text { design }\end{array}$ & $\begin{array}{l}\text { Number of } \\
\text { participants/ } \\
\text { experimental } \\
\text { group/control } \\
\text { group }\end{array}$ & $\begin{array}{l}\text { Age (mean of } \\
\text { the } \\
\text { experimental } \\
\text { group)/sex } \\
\text { (male, \%) }\end{array}$ & $\begin{array}{l}\text { Diagnostic } \\
\text { criteria for } \\
\text { ADHD }\end{array}$ & $\begin{array}{l}\text { Atopic disease/method used } \\
\text { for assessing atopic } \\
\text { diseases }\end{array}$ & $\begin{array}{l}\text { Outcome } \\
\text { scale }\end{array}$ & $\begin{array}{l}\text { Overall risk } \\
\text { of bias }\end{array}$ \\
\hline $\begin{array}{l}\text { Yuksel et al., } \\
2008^{64}\end{array}$ & Turkey & $\begin{array}{l}\text { Cross- } \\
\text { sectional }\end{array}$ & $100 / 62 / 38$ & $\begin{array}{l}7-12 \text { years } \\
(9.2) / 57 \%\end{array}$ & DSM-IV & $\begin{array}{l}\text { Asthma/physician's } \\
\text { diagnosis (GINA 2006) }\end{array}$ & $\begin{array}{l}\text { Conner's } \\
\text { Parent } \\
\text { Rating } \\
\text { Scale }\end{array}$ & Included \\
\hline $\begin{array}{l}\text { Camfferman } \\
\text { et al., } \\
2010^{32}\end{array}$ & Australia & $\begin{array}{l}\text { Cross- } \\
\text { sectional }\end{array}$ & $107 / 77 / 30$ & $\begin{array}{l}6-16 \text { years } \\
(9.9) / 46.72 \%\end{array}$ & $\begin{array}{l}\text { Conner's } \\
\text { Parent } \\
\text { Rating } \\
\text { Scale- } \\
\text { Revised }\end{array}$ & $\begin{array}{l}\text { Atopic dermatitis/physician's } \\
\text { diagnosis (Hanifin and Rajka } \\
\text { criteria) }\end{array}$ & $\begin{array}{l}\text { Conner's } \\
\text { Parent } \\
\text { Rating } \\
\text { Scale }\end{array}$ & Included \\
\hline $\begin{array}{l}\text { Lee et al., } \\
2014^{67}\end{array}$ & $\begin{array}{l}\text { Republic } \\
\text { of Korea }\end{array}$ & $\begin{array}{l}\text { Cross- } \\
\text { sectional }\end{array}$ & $160 / 87 / 73$ & $\begin{array}{l}6-13 \text { years } \\
(8.49) / 39.4 \%\end{array}$ & DSM-IV & $\begin{array}{l}\text { Allergic rhinitis/physician's } \\
\text { diagnosis (ARIA guideline) }\end{array}$ & ARS & Included \\
\hline $\begin{array}{l}\text { Yang et al., } \\
2014^{68}\end{array}$ & Taiwan & $\begin{array}{l}\text { Cross- } \\
\text { sectional }\end{array}$ & $122 / 93 / 29$ & $\begin{array}{l}6-14 \text { years } \\
(10.78) / 52.2 \%\end{array}$ & DSM-IV-TR & $\begin{array}{l}\text { Allergic rhinitis/physician's } \\
\text { diagnosis (ARIA 2008) + IgE } \\
\text { test (MAST or Phadiatop } \\
\text { tests) }\end{array}$ & $\begin{array}{l}\text { SNAP-IV } \\
\text { (parent) }\end{array}$ & Included \\
\hline $\begin{array}{l}\text { Catal et al., } \\
2016^{69}\end{array}$ & Turkey & $\begin{array}{l}\text { Cross- } \\
\text { sectional }\end{array}$ & $154 / 80 / 74$ & $3-5$ year & $\mathrm{ECl}-4$ & $\begin{array}{l}\text { Atopic dermatitis/physician's } \\
\text { diagnosis (Hanifin and Rajka } \\
\text { criteria) }\end{array}$ & $\mathrm{ECl}-4$ & Included \\
\hline $\begin{array}{l}\text { Hammer- } \\
\text { Helmich et } \\
\text { al., } 2016^{25}\end{array}$ & Denmark & $\begin{array}{l}\text { Cross- } \\
\text { sectional }\end{array}$ & $9036 / 2433 / 6603$ & $\begin{array}{l}3-15 \text { years } \\
\text { (NA) } / 49.5 \%\end{array}$ & SDQ & $\begin{array}{l}\text { Eczema, asthma, and hay } \\
\text { fever/Questionnaire }\end{array}$ & SDQ & Included \\
\hline $\begin{array}{l}\text { Yang et al., } \\
2016^{22}\end{array}$ & Taiwan & $\begin{array}{l}\text { Case- } \\
\text { control }\end{array}$ & $99 / 68 / 31$ & $\begin{array}{l}6-14 \text { years } \\
(9.25) / 82.4 \%\end{array}$ & DSM-IV & $\begin{array}{l}\text { Allergic rhinitis/Physician's } \\
\text { diagnosis + IgE test (MAST } \\
\text { or Phadiatop tests) }\end{array}$ & $\begin{array}{l}\text { SNAP-IV } \\
\text { (parent) }\end{array}$ & Included \\
\hline $\begin{array}{l}\text { Feng et al., } \\
2017^{71}\end{array}$ & China & $\begin{array}{l}\text { Cross- } \\
\text { sectional }\end{array}$ & $643 / 248 / 320$ & $\begin{array}{l}6-12 \text { years } \\
(9.25) / 51.9 \%\end{array}$ & DSM-IV & $\begin{array}{l}\text { Allergic rhinitis/Physician's } \\
\text { diagnosis (ARIA 2008) + skin } \\
\text { prick test }\end{array}$ & SNAP-IV & Included \\
\hline $\begin{array}{l}\text { Kuniyoshi et } \\
\text { al., } 2018^{26}\end{array}$ & Japan & $\begin{array}{l}\text { Cross- } \\
\text { sectional }\end{array}$ & $9954 / 1641 / 8313$ & $\begin{array}{l}7-14 \text { years } \\
(10.42) / 49.9 \%\end{array}$ & SDQ & $\begin{array}{l}\text { Eczema/ISAAC Eczema } \\
\text { Symptom questionnaire }\end{array}$ & SDQ & Included \\
\hline $\begin{array}{l}\text { Schmitt et } \\
\text { al., } 2018^{73}\end{array}$ & Germany & $\begin{array}{l}\text { Case- } \\
\text { control }\end{array}$ & $89 / 35 / 45$ & $\begin{array}{l}6-12 \text { years } \\
(9.9) / 62.9 \%\end{array}$ & ICD-10 & $\begin{array}{l}\text { Atopic } \\
\text { dermatitis/Dermatologist's } \\
\text { diagnosis (UK Working Party } \\
\text { Criteria) }\end{array}$ & FBB-HKS & Included \\
\hline $\begin{array}{l}\text { Feng et al., } \\
2020^{76}\end{array}$ & China & $\begin{array}{l}\text { Cross- } \\
\text { sectional }\end{array}$ & $273 / 89 / 184$ & $\begin{array}{l}6-12 \text { years } \\
(8.3) / 62.63 \%\end{array}$ & SNAP-IV & $\begin{array}{l}\text { Atopic } \\
\text { dermatitis/Dermatologist's } \\
\text { diagnosis (UK criteria) }\end{array}$ & SNAP-IV & Included \\
\hline $\begin{array}{l}\text { Kuo et al., } \\
2020^{47}\end{array}$ & Taiwan & $\begin{array}{l}\text { Cross- } \\
\text { sectional }\end{array}$ & $191 / 109 / 92$ & (6.59)/54.44\% & SNAP-IV & $\begin{array}{l}\text { Atopic dermatitis, asthma, } \\
\text { and allergic } \\
\text { rhinitis/Physician's } \\
\text { diagnosis }\end{array}$ & SNAP-IV & $\begin{array}{l}\text { "Seek } \\
\text { further } \\
\text { information" }\end{array}$ \\
\hline
\end{tabular}

Abbreviations: ADHD, Attention-Deficit/Hyperactivity Disorder; DSM-IV, Diagnostic and Statistical Manual of Mental Disorders; GINA 2006, Global Initiative for Asthma, 2006; ARIA, Allergic Rhinitis and its Impact on Asthma; ARS, ADHD Rating Score; MAST, multiple-antigen simultaneous test; The Early Childhood Inventory-4; SNAP-IV, Swanson, Nolan, and Pelham Questionnaire; SDQ, Strengths and Difficulties Questionnaire; ICD-10, International Classification of Diseases, Tenth Revision; FBB-HKS, The German ADHD Rating Scale 
Figures

a.

Study

SMD $[95 \% \mathrm{Cl}]$

Catal et al., 2016

Hammer-Heimich et al., 2016

Camfferman et al., 2010

Yuksel et al., 2008

Lee et al., 2014

Yang et al., 2014

Yang et al., 2016

Feng et al., 2017

Schmitt et al., 2017

Kuo et al., 2020

Feng et al., 2020

Kuniyoshi et al.

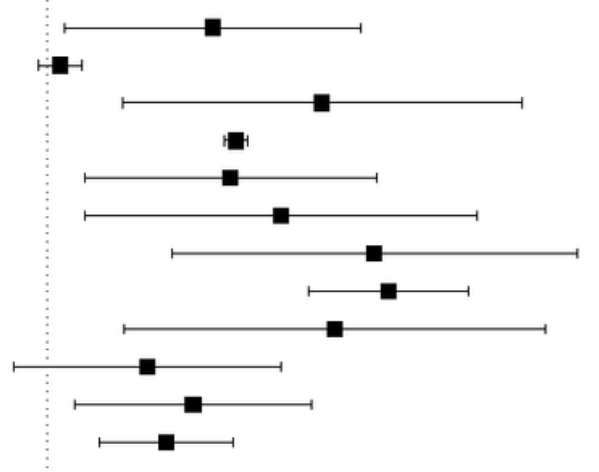

$0.36[0.04,0.68]$

$0.03[-0.02,0.07]$

$0.59[0.16,1.02]$

$0.41[0.38,0.43]$

$0.39[0.08,0.71]$

$0.50[0.08,0.92]$

$0.70[0.27,1.14]$

$0.74[0.56,0.91]$

$0.62[0.17,1.07]$

$0.22[-0.07,0.50]$

$0.31[0.06,0.57]$

$0.26[0.11,0.40]$

Random-effects model $\left(Q=227.88, \mathrm{df}=11, \mathrm{p}=0.00 ; \mathrm{I}^{2}=92.8 \%\right)$

$0.39[0.26,0.53]$

\begin{tabular}{|c|c|c|c|}
\hline$\Gamma$ & 1 & $T$ & 1 \\
\hline-0.5 & 0 & 0.5 & 1 \\
\hline
\end{tabular}

\section{Figure 1}

(a) Forest plot of the meta-analysis of the severity of total ADHD symptoms in childhood and the presence of atopic diseases. (b) Funnel plot of the metaanalysis of the severity of total ADHD symptoms in childhood and the presence of atopic diseases. (c) Forest plot of the meta-analysis of the severity of hyperactivity/impulsivity in childhood and the presence of atopic diseases. (d) Funnel plot of the meta-analysis of the severity of hyperactivity/impulsivity in childhood and the presence of atopic diseases. (e) Forest plot of the meta-analysis of the severity of inattention in childhood and the presence of atopic diseases. (f) Funnel plot of the meta-analysis of the severity of inattention in childhood and the presence of atopic diseases. Abbreviations: SD, standard deviation; $\mathrm{Cl}$, confidence interval; SMD, standardized mean difference 

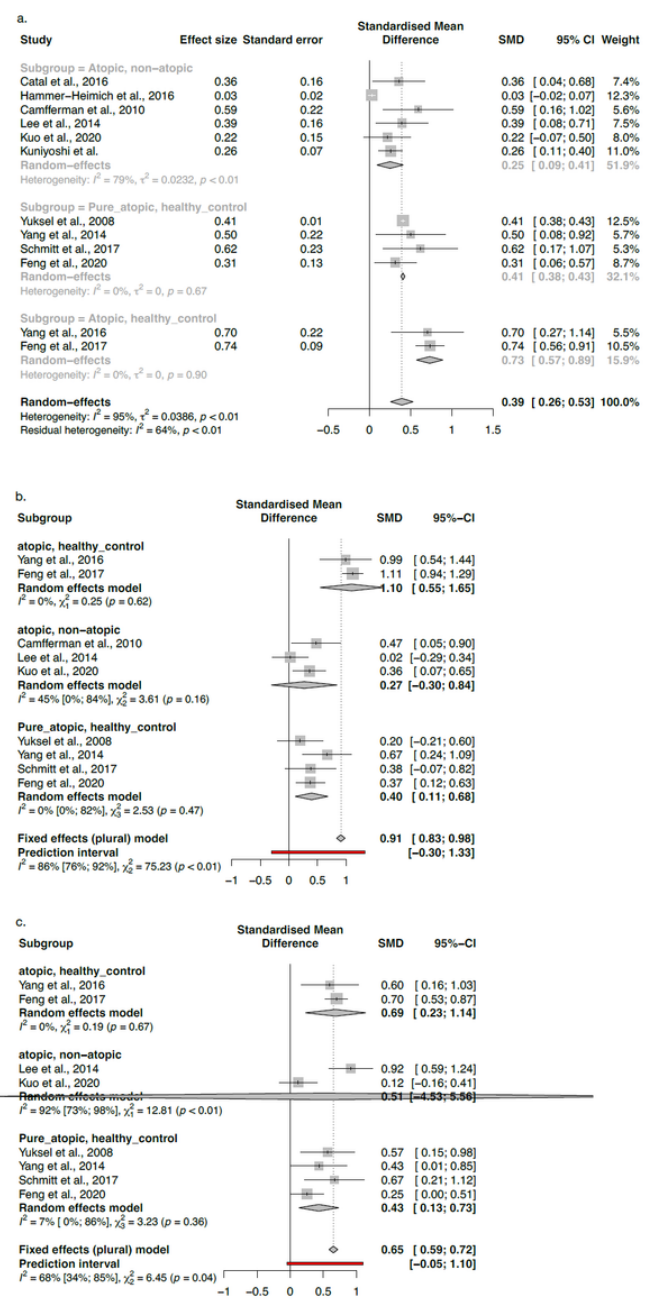

\section{Figure 2}

a) Forest plot of the subgroup analysis of the severity of total ADHD symptoms in childhood and the presence of atopic diseases; different inclusion and exclusion criteria for ADHD were applied. (b) Forest plot of the subgroup analysis of the severity of hyperactivity/impulsivity in childhood and the presence of atopic diseases; different inclusion and exclusion criteria for ADHD were applied. (c) Forest plot of the subgroup analysis of the severity of inattention in childhood and the presence of atopic diseases; different inclusion and exclusion criteria for ADHD were applied. Abbreviations: Cl, confidence interval; SMD, standardized mean difference 


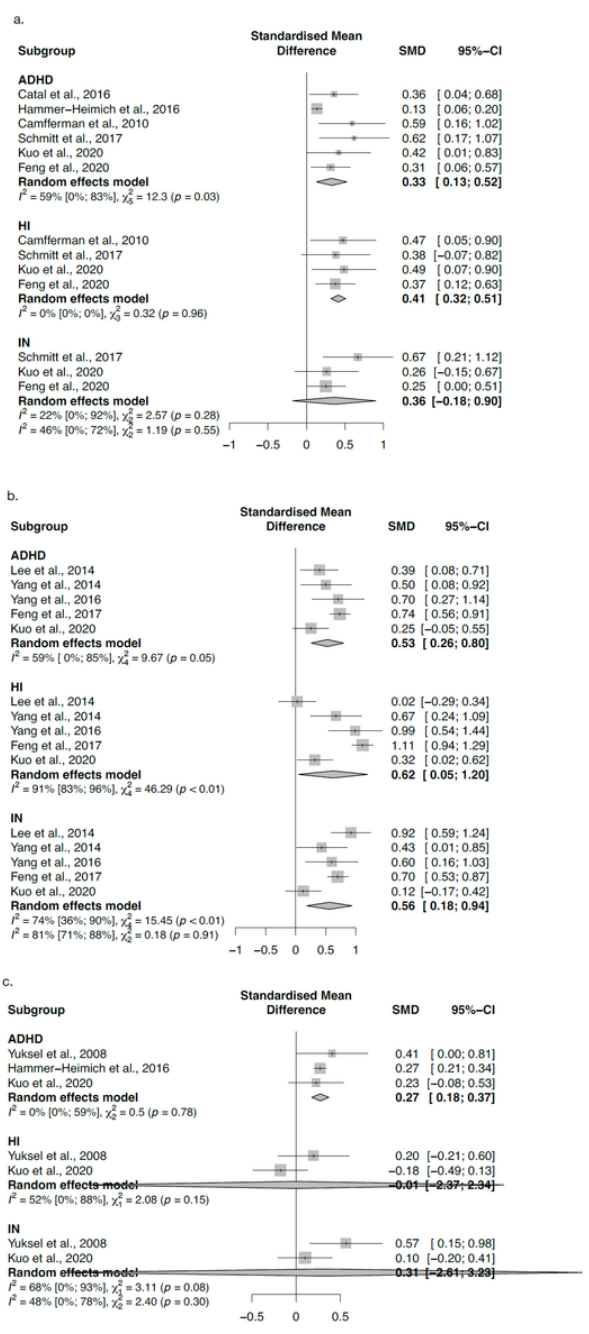

\section{Figure 3}

a) Forest plot of the subgroup analysis of the severity of total ADHD symptoms, hyperactivity/impulsivity, and inattention in children with atopic dermatitis. (b) Forest plot of the subgroup analysis of the severity of total ADHD symptoms, hyperactivity/impulsivity, and inattention in children with allergic rhinitis. (c) Forest plot of the subgroup analysis of the severity of total ADHD symptoms, hyperactivity/impulsivity, and inattention in children with asthma Abbreviations: $\mathrm{Cl}$, confidence interval; SMD, standardized mean difference

\section{Supplementary Files}

This is a list of supplementary files associated with this preprint. Click to download.

- PRISMAchecklist.pdf

- Supplementary0725.pdf 